\title{
Beach Molluscan Thanatocoenoses in Possjet Bay, Sea of Japan: Comparison between Open and Sheltered Beaches
}

\author{
KONSTANTIN A. LUTAENKO \\ Laboratory of Benthos Ecology, Institute of Marine Biology, \\ Far East Branch of Russian Academy of Sciences, and Zoological \\ Museum, Far East State University
}

\begin{abstract}
LUTAENKO, Konstantin A. (Laboratory of Benthos Ecology, Institute of Marine Biology, Far East Branch of Russian Academy of Sciences, and Zoological Museum, Far East State University). 1994. Beach Molluscan Thanatocoenoses in Possjet Bay, Sea of Japan : Comparison between Open and Sheltered Beaches. Benthos Research, 47: 1-12.

Molluscan thanatocoenoses have been studied in 16 areas of the seashore of Possjet Bay (northwestern part of the Sea of Japan), and 58 species of bivalves, referred to 42 genera and 23 families, were identified. This is about $60 \%$ of the total number of bivalve molluscs inhabiting the Bay and surrounding waters. Peculiarities in the composition and taphonomy of the thanatocoenoses are described. The taxonomic composition of the beach thanatocoenoses of bivalve molluscs commonly reflects environmental variability in the shallow waters of Possjet Bay. There seems to be minimal postmortem migration of molluscan shells in Possjet Bay.
\end{abstract}

\section{Introduction}

Molluscan shells are one of the most common and sometimes a dominant component of modern beach sediments (DAvis, 1985). This circumstance, together with the lack of technical difficulties, may explain the interest of actuopaleontologists in beach thanatocoenoses as an object for taphonomic studies. The main em-

Received August 3, 1993 : Accepted April 15, 1994 phasis in such works has been on the transport, sorting, orientation and destruction of shell material under different hydrodynamic conditions, because investigations of recent death assemblages give good evidence for paleoecological and taphonomic interpretation of fossil molluscan assemblages. This has led us to undertake a taphonomic study in some areas of Peter the Great Bay - one of the largest bays of the Sea of Japan. 


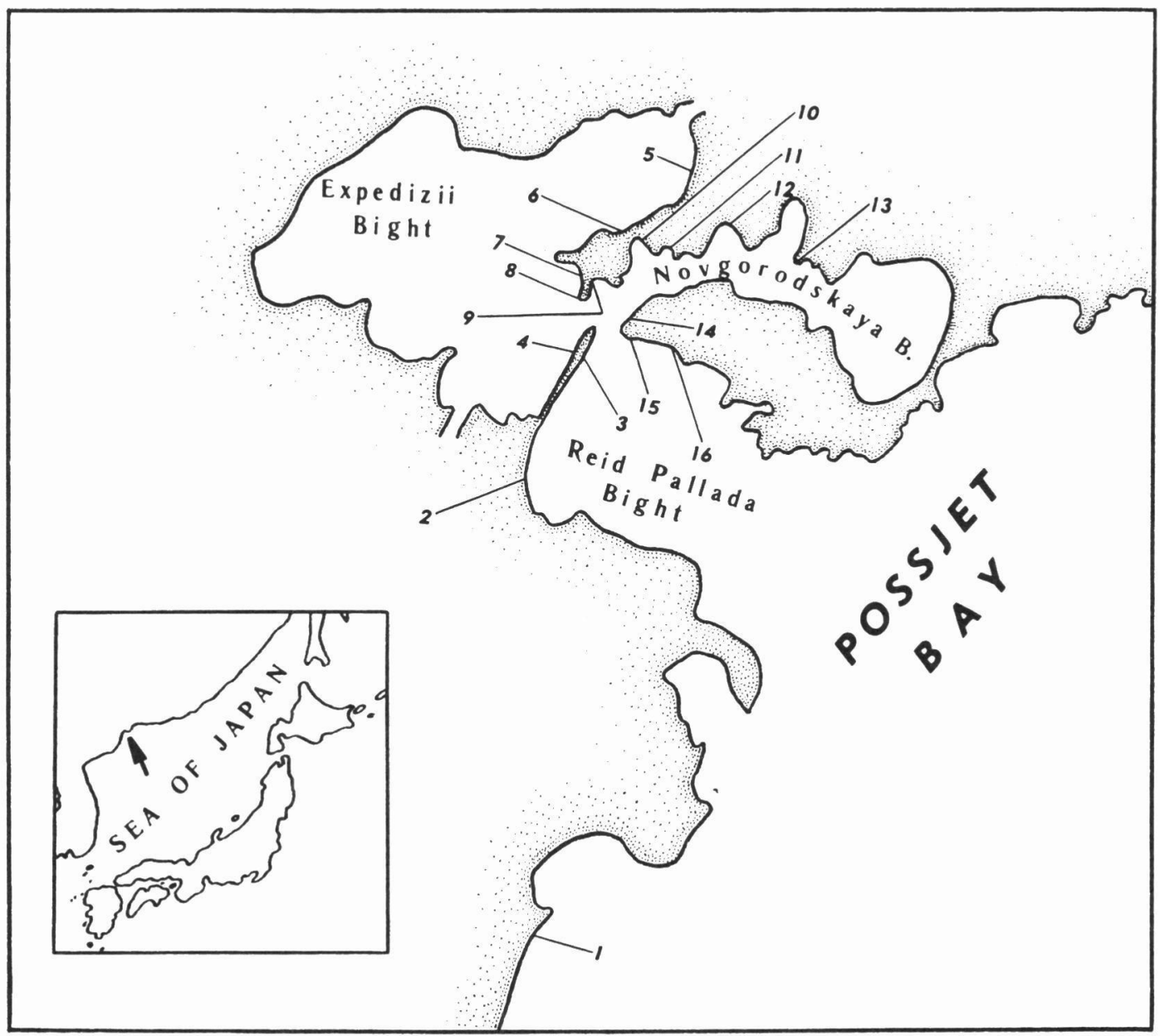

Fig. 1 Map of the study sites within Possjet Bay.

\section{Materials and Methods}

For this study, sixteen beach sites (Fig. 1) in Possjet Bay (southwestern part of Peter the Great Bay) were selected for fieldwork in 19881989. Most of these areas are situated in the three large bights of Possjet Bay - Reid Pallada Bight (sites 2, 3, 15, 16), Expedizii Bight (sites 48 ) and Novgorodskaya Bight (sites 10-14). Some of the sites were from about 1 to $3 \mathrm{~km}$ long, but in some cases only several hundred metres. The sites were sampled qualitatively for the compilation of a molluscan species list. Shell damage ( i. e. abrasion, dissolution traces, periostracum preservation, etc.) was evaluated in the laboratory. The field observations included examinations of beach sediment type and shoreline morphology.

In order to compare the composition of thanatocoenoses, Kulchzynsky's similarity indices were used (PEsEnKo, 1982):

$$
\mathrm{I}_{\mathrm{k}}=0.5\left[\frac{\mathrm{C}}{\mathrm{N}_{1}}+\frac{\mathrm{C}}{\mathrm{N}_{2}}\right]
$$


where $\mathrm{N}_{1}$ and $\mathrm{N}_{2}$ are the number of species found in sites 1 or 2 , respectively; $\mathrm{C}$ is the number of species common to both sites. In cases of complete similarity between two sites, the value of the index is 1 , and in the opposite case 0 .

\section{Local Setting}

Possjet Bay is one of the embayments inside Peter the Great Bay and it extends inland a distance of $31 \mathrm{~km}$. According to Golikov and Scarlato (1967a, 1968), two types of bights open and semi-closed, can be distinguished in Possjet Bay. The average depth of Reid Pallada Bight is about $15.1 \mathrm{~m}$, and that of the two other bights $2.9 \mathrm{~m}$ (VyshKVARTZEv, 1984). The bottom sediments in Expedizii and Novgorodskaya Bights are represented mainly by silt, partly mixed with shell debris and sand. A gravelpebble type of sediment with rare inclusions of boulders is distributed along the eroding coastlines ? of Reid Pallada Bight. The psephitic (pebbly, gravelly and rocky) beaches are interrupted? by a large number of cliffs. Areas of sand accumulation are distributed in the semiclosed Expedizii and Novgorodskaya Bights. Nasimova (Churhado) Spit, which is about 9 $\mathrm{km}$ long, is one such example. One common feature of the semi-closed bights is that the beaches are covered by slowly? decomposing sea grass, Zostera marina.

Possjet Bay is situated in the monsoonal climatic zone. The summer is humid, with much rainfall and fog. Winter is dry with quite low temperatures for these latitudes, and strong winds. Tropical cyclones (typhoons) during the second half of the summer, accompanied by intense precipitation and stormy winds, have a strong influence on the nearshore communities.

The semi-closed bights of Possjet Bay are quiet, and these regions therefore serve as traps for alluvial sediments. In winter time (from December to March), the semi-closed bays are completely covered by ice, which prevents shell accumulation on the beaches. On the other hand,
Reid Pallada Bight is known for its active wave action.

Significant differences between Reid Pallada Bight and the semi-closed Expedizii and Novgorodskaya Bights are also found in their hydrological conditions. The waters of the semiclosed bights warm up strongly (up to $28-30^{\circ} \mathrm{C}$ ) during summer time, and in winter they become cooler than in Reid Pallada Bight and other open areas. In consequence of its shallow waters and the inflow of five rivers and small streams draining an area of $910 \mathrm{~km}^{2}$, the subsurface salinity in Expedizii Bight may go as low as $5 \%$ (VyshkVARTZev, 1984). The salinity in winter seems to be the same in all the regions of the Bay and reaches about 33-34 \%.

\section{Results}

Fifty-eight species of bivalve molluscs referred to 42 genera and 23 families have been identified from the beach zone (Table 1 ). In comparison, over 100 species of Bivalvia inhabit Possjet Bay and surrounding areas down to a depth of 120 m (Golikov \& Scarlato, 1967b, 1971; Scarlato, 1981; Scarlato \& Kafanov, 1988; Kafanov, 1991). Four species, Crassostrea gigas, Ruditapes philippinarum (frequency of occurence of both? - 93.7\%), Chlamys farreri and Mya japonica (frequency of occurence of both? $-87.5 \%$ ) are the most common along the beaches of Possjet Bay. The first two species occurred in all 15 investigated areas, the last two in 14 of them. Preliminary data from the investigation of thanatocoenoses in other regions of Peter the Great Bay (Lutaenko, 1990) suggest that $C$. gigas and $R$. philippinarum are also quite common in the beach zone of Amur, Ussuri and Vostok Bays.

1. Open coasts. The distinctive feature of the open coast sites (areas 1-3, 15, 16) is strong, periodical wave influence on the upper subtidal and beach zones. In consequence, accumulation and reworking of shells occurs constantly, except in winter time when this is prevented by 
Table 1 Species composition of the bivalve thanatocoenoses from beaches in Possjet Bay.

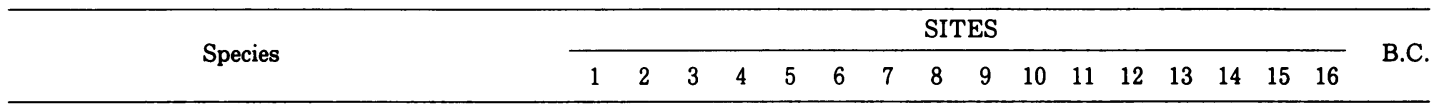

Family Nuculidae

Acila insignis (GOULD)

Family Mytilidae

Modiolus Kurilensis BERNARD

Musculista senhousia (BENSON)

Mytilus edulis L. s.l.

Mytilus coruscus GOULD

Mytilus galloprovincialis LAMARCK

Crenomytilus grayanus (DUNKER)

Family Septiferidae

Septifer Keenae NOMURA

Family Lithophagidae

Adula falcatoides HABE

Family Glycymerididae

Glycymeris yessoensis (SOWERBY)

Family Arcidae

Anadara broughtoni (SCHRENCK)

Arca boucardi JOUSSEAUME

Family Ostroidae

Crassostrea gigas (THUNBERG)

Family Pectinidae

Chlamys farreri JONES et PRESTON

Swiftopecten swifti (BERNARDI)

Mizuhopecten yessoensis (JAY)

Family Laternulidae

Laternula limicola (REEVE)

Family Lyonsiidao

Agriodesma navicula (ADAMS et REEVE)

Family Hiatellidae

Panomya arctica (LAMARCK)

Panope abrupta (CONRAD)

Family Cardiidao

Keenocardium californiense (DESHAYES)

Family Ungulinidae

Diplodonta semiasperoides NOMURA

Felaniella usta (GoULD)

Family Tollinidae

Megangulus venulosus (SCHRENCK)

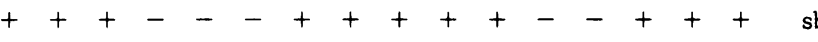

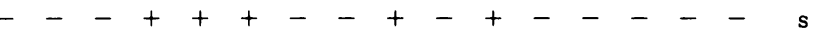

$++++--+-+++-+\infty \mathrm{w}$

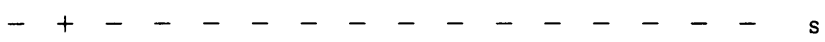

$+--\quad-\quad-\quad-\quad-\quad-\quad-\quad-\quad$ *

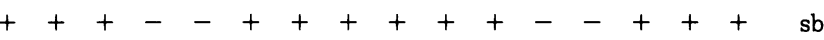

$-\quad-\quad-\quad-+-++-+--\quad s$

$-\quad-\quad-\quad-\quad-\quad-\quad-\quad-+$ - $-\mathrm{sb}$

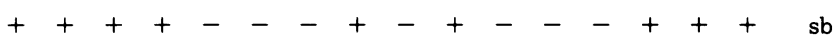

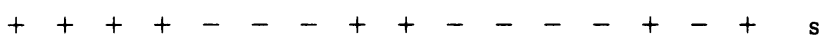

$+-++-+++++++-s^{-}$

+-++++++++++++ s

$-+++-+++++++++4$

$-++-----\infty \mathrm{sb}$

$-+++--++++++t_{+}+\mathrm{sb}$

Megangulus zyonoensis (HATAI et NISHIYAMA)

Macoma balthica (L.) s.l.

Macoma incongrua (v. MARTENS)

Macoma sectior OYAMA

Macoma orientalis SCARLATO

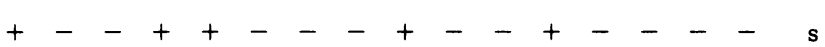

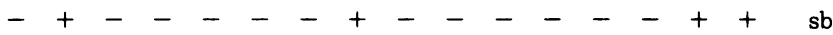

$++--------b-b$

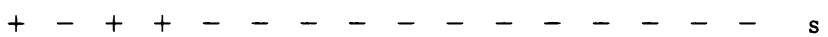

Macoma tokyoensis MAKIYAMA

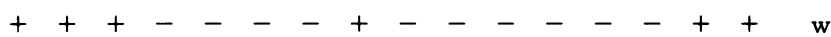

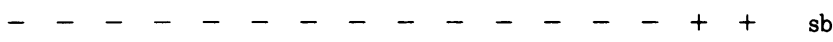

$++++---\infty-\infty-\infty$ sb

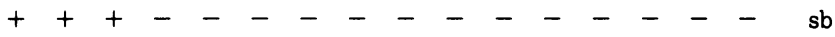

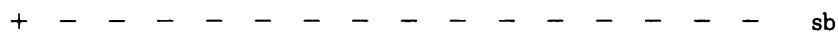

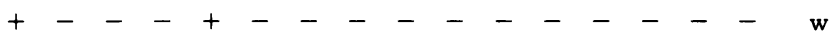

$-++++++++++t+-t$

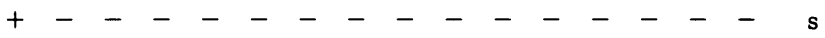

$-+++----+--\infty \mathrm{w}$

$-\quad+--\quad-+-+-\quad-\quad-\quad-\quad s$ 


\begin{tabular}{|c|c|c|c|c|c|c|c|c|c|c|c|c|c|c|c|c|c|}
\hline \multirow{2}{*}{ Species } & \multicolumn{16}{|c|}{ SITES } & \multirow{2}{*}{ B.C. } \\
\hline & 1 & 2 & 3 & 4 & 5 & 6 & 7 & 8 & 9 & 10 & 11 & 12 & 13 & 14 & 15 & 16 & \\
\hline Macoma contabulata (DESHAYES) & - & - & - & - & + & - & - & - & - & - & - & - & - & - & - & - & $\mathbf{s}$ \\
\hline Heteromacoma irus (HANLEY) & - & + & - & - & - & - & - & + & - & - & - & - & - & + & + & + & $\mathbf{s}$ \\
\hline \multicolumn{18}{|l|}{ Family Psammobiidao } \\
\hline Gari kazusensis (YOKOY АMA) & - & + & - & - & - & - & - & + & - & - & + & - & - & - & + & + & $\mathbf{s b}$ \\
\hline Nuttallia ezonis (KURODA et HABE) & + & + & + & + & - & - & + & - & - & - & - & - & - & - & - & - & sb \\
\hline Nuttallia obscurata (REEVE) & - & + & - & + & - & - & + & - & - & - & - & - & - & - & - & - & $\mathbf{s}$ \\
\hline \multicolumn{18}{|l|}{ Family Corbiculidae } \\
\hline Corbicula japonica PRIME & + & - & + & - & + & - & + & - & - & + & - & - & - & - & - & - & $* *$ \\
\hline \multicolumn{18}{|l|}{ Family Veneridae } \\
\hline Callista brevisiphonata (CARPENTER) & - & + & + & - & - & - & - & + & - & - & + & - & - & + & + & + & sb \\
\hline Dosinia angulosa (PHILPPI) & - & - & - & - & - & + & - & - & - & - & + & - & - & - & - & - & $\mathbf{t}$ \\
\hline Dosinia japonica (REEVE) & + & + & + & + & - & - & - & + & - & - & - & - & - & - & - & - & $\mathbf{s}$ \\
\hline Ruditapes philippinarum (ADAMS et REEVE) & + & + & + & + & + & + & + & + & + & + & + & + & + & + & - & + & $\mathbf{s}$ \\
\hline Mercenaria stimpsoni (GoULD) & + & + & + & - & - & - & - & - & - & - & - & - & - & - & - & - & $\mathbf{s b}$ \\
\hline Protothaca euglypta (SOWERBY) & - & + & - & - & - & - & - & - & - & - & - & - & - & + & + & + & sb \\
\hline Prothotaca jedoensis (IISCHKE) & - & + & + & - & - & - & - & + & - & + & + & + & - & + & + & + & $\mathbf{s}$ \\
\hline Callithaca adamsi (REEVE) & + & - & + & - & - & - & - & - & - & - & - & - & - & - & - & - & sb \\
\hline \multicolumn{18}{|l|}{ Family Aloididao } \\
\hline Potamocorbula amurensis (SCHRENCK) & - & + & - & + & + & + & - & + & + & - & - & - & - & - & - & - & $\mathbf{s}$ \\
\hline \multicolumn{18}{|l|}{ Family Cultellidae } \\
\hline Siliqua alta (BRODERIP et SOWERBY) & + & - & + & - & - & - & - & - & - & - & - & - & - & - & - & - & $\mathbf{w}$ \\
\hline \multicolumn{18}{|l|}{ Family Solenidae } \\
\hline Solen corneus LAMARCK & - & - & - & + & - & - & - & - & - & - & - & - & - & - & - & - & $\mathrm{t}$ \\
\hline Solen krusensterni & + & - & + & + & - & - & - & - & - & - & - & - & - & - & - & - & $\mathbf{s b}$ \\
\hline \multicolumn{18}{|l|}{ Family Mactridae } \\
\hline Mactra chinensis PHILIPPI & + & + & + & + & - & - & - & - & - & - & - & - & - & - & - & - & $\mathbf{s}$ \\
\hline Mactra veneriformis DESHAYES & - & + & + & + & + & - & - & - & + & - & - & - & - & - & - & - & $\mathbf{s}$ \\
\hline Spisula sachalinensis (SCHRENCK) & + & + & + & + & - & + & - & - & + & - & - & + & - & - & - & + & sb \\
\hline Spisula polynyma (STIMPSON) & - & + & - & - & - & - & - & - & - & - & - & - & - & - & - & - & $\mathbf{w}$ \\
\hline \multicolumn{18}{|l|}{ Family Myidae } \\
\hline Mya uzenensis NOMURA et ZINBO & - & + & + & - & - & - & - & - & - & - & - & - & - & + & + & + & $\mathbf{w}$ \\
\hline Mya japonica JAY & + & + & + & + & + & + & - & + & + & + & + & - & + & + & + & + & $\mathbf{w}$ \\
\hline \multicolumn{18}{|l|}{ Family Pholadidao } \\
\hline Barnea manilensis (PHILIPPI) & + & - & - & - & - & - & - & - & - & - & - & - & - & - & - & - & $\mathbf{s}$ \\
\hline Barnea dilatata (SOULEYET) & + & - & - & - & - & - & - & - & - & - & - & - & - & - & - & - & $\mathbf{s}$ \\
\hline Zirfaea cf. crispata (L.) & + & - & - & - & - & - & - & - & - & - & - & - & - & - & - & - & $? \mathrm{w}$ \\
\hline
\end{tabular}

"+": present, "-" : absent

B.C. : biogeographical characteristics ( $\mathrm{s}=$ subtropical + subtropical-subboreal; $\mathrm{sb}=$ subboreal; $\mathrm{b}=$ boreal-arctic; $\mathrm{w}=$ widely distributed boreal + amphiboreal (circum-boreal); $\mathrm{t}=$ tropical-subtropical species)

* : recent Mediterranean invader to the Sea of Japan

* * : brackish-water species 
shore ice. A portion of these shells, especially those with thin and fragile valves, are subject to intense decortication and become reduced to shelly detritus. Another portion of the shells is broken into bigger fragments. Such fragmented and strongly decorticated valves dominate at the psephitic beaches. The distribution of shell material on the beaches is not homogeneous: more often it occurs along the upper boundary, marking the maximal wave-action line, but more sparsely between the rocks and cliff caverns. Long exposure of shell material on the beach caused its further destruction through the action of temperature fluctuations and precipitation. The shells often lose their natural color, and the periostracum and pearl layer begin to deteriorate. According to our observations, the valves of some molluscs are particularly sensitive to variations in temperature and moisture. The relatively thick valves of Mytilus coruscus and Agriodesma navicula, for instance, began to crack quite rapidly.

After strong storms caused by typhoons, the number of living molluscs and shells with soft tissues attached in increases significantly the beach zone. During the last 20 years, accumulations of molluscs have been observed in Possjet Bay after Typhoon "Fren" in 1976 (RAKov \& Kucheryavenko, 1977), "Alis" in 1982 (KALASHNiKov, 1984) and "Vera" (VyshKVARTZEV et al., 1990). After Typhoon "Fren", more than 780,000 specimens of molluscs were thrown up on a beach about $8 \mathrm{~km}$ in length ( $\mathrm{RAKOV}_{\mathrm{A}} \&$ Kucheryavenko, 1977). According to Ansell et al. (1988), mass beach accumulation of infaunal bivalves may be promoted by some species of algae that use their shells as a substrate. Algae attaching to bivalves have a significant sailing capacity and often can be found thrown up on the beach with other animals after strong storms. This kind of event has not been observed in Possjet Bay, but disarticulated valves with attached algae of the genera Sargassum and Codium have been observed rarely in the open part of the Bay.
The total number of species occuring in the open sites was 53 , varying from place to place from 20 species (area 15) to 34 (areas 2, 3). The taxonomic composition of the bivalves on the open beaches is distinguished by a high diversity and the presence of molluscs inhabiting different types of substrate. Based on the last feature, two major types of thanatocoenoses can be distinguished: 1) those with a predominance of psammophilic species distributed on coasts with widely developed sandy beaches; 2) those with a predominance of species inhabiting hard and mixed substrates and distributed mainly on the psephitic beaches of eroding? coasts. The most characteristic elements of the first type of thanatocoenoses are the common infaunal species of the upper subtidal environment, Spisula sachalinensis and Mactra chinensis. These molluscs often attain their densest populations at depths of 3 to 5 metres; the density of settlement of $S$. sachalinensis may reach up to 10 specimens per square metre (GoLikov \& SCARLATO, 1967b). Megangulus venulosus, Dosinia japonica and Mercenaria stimpsoni, also typical infaunal specimens of the sandy wave-action zone, occur more sparsely. Molluscs attaching with byssus to hard substrata (Crenomytilus grayanus, Modiolus kurilensis) or inhabiting mainly gravel and pebbles bottoms with a mixture of rocks and sand (Glycymeris yessoensis, Swiftopecten swifti), and also those from a different mixed substrate, muddy with a mixture of gravel, pebbles, shell material and stones (Callista brevisiphonata, Saxidomus purpuratus, Protothaca euglypta, etc.), are typical elements of second type of thanatocoenosis.

2. Semi-closed regions. Expedizii and Novgorodskaya Bights (areas 4-7, 9-14) belong to this type of embayment. As we have mentioned above, the significant ecological features of these bights are the limited water exchange with the open sea, strong water heating during the summer season, and partial fresh-water dilution, varying seasonally. 
Despite the mild water movements, in the majority of study sites, molluscan shells are a common component in the beach sediments. Significant accumulations of shell material represented by $C$. gigas, $R$. philippinarum and Arca boucardi valves have been observed in areas 7 and 14. The distinctive feature of the molluscan thanatocoenoses of the semi-closed bights is the occurence of brackish-water and euryhaline marine species that have a propensity to inhabit regions that are subject to freshwater dilution: Corbicula japonica, Potamocorbula amurensis, Macoma balthica, Nuttallia obscurata, etc. In some places, particularly near river mouths, they begin to dominate on the beach.

Destruction of the shell material in the beach zone of the semi-closed bights appears to be quite different from that along the open coast, and is generally connected with chemical action. The process of dissolution begins in the upper subtidal zone, sometimes during the life of the mollusc (in this case, the beak, lacking a periostracum, becomes the most strongly decorticated). Water stagnation and rapid precipitation of decomposing plant remains promote an enrichment of organic acids and carbon dioxide in the beach zone. Mass accumulations of algae and sea grasses are common in this zone; they are commonly associated with silty-sandy beaches. In the low hydrodynamic conditions during the summer season, the decomposition of these accumulations resulted, in several areas of Expedizii Bight, in the hydrogen sulfide pollution of the intertidal zone. This environment is not condusive to significant shell accumulations. Thus, any shell accumulation on the beaches of the semi-closed bights usually takes place as a consequence of strong storms.

The list of bivalves collected on the beaches of the semi-closed bights comprises 40 species. The number of species varies significantly among the sites, from 6 (area 13) to 25 (area 4).

Table 2 Values of KULChZHYNSKY's similarity indices $\left(I_{k}\right)$ and the number of common species $\left(N_{c}\right)$ between beach areas of Possjet Bay (see Fig. 1).

\begin{tabular}{|c|c|c|c|c|c|c|c|c|c|c|c|c|c|c|c|c|}
\hline $\mathrm{N}_{\mathrm{c}}{ }^{\mathrm{I}} \mathrm{k}$ & 1 & 2 & 3 & 4 & 5 & 6 & 7 & 8 & 9 & 10 & 11 & 12 & 13 & 14 & 15 & 16 \\
\hline 1 & & 0.462 & 0.678 & 0.554 & 0.369 & 0.369 & 0.493 & 0.389 & 0.439 & 0.426 & 0.319 & 0.358 & 0.350 & 0.410 & 0.288 & 0.370 \\
\hline 2 & 15 & & 0.735 & 0.604 & 0.301 & 0.421 & 0.481 & 0.674 & 0.552 & 0.505 & 0.529 & 0.422 & 0.258 & 0.662 & 0.675 & 0.782 \\
\hline 3 & 22 & 25 & & 0.675 & 0.361 & 0.481 & 0.662 & 0.561 & 0.637 & 0.689 & 0.573 & 0.562 & 0.517 & 0.662 & 0.556 & 0.675 \\
\hline 4 & 15 & 17 & 19 & & 0.530 & 0.596 & 0.530 & 0.479 & 0.739 & 0.521 & 0.452 & 0.611 & 0.553 & 0.904 & 0.275 & 0.458 \\
\hline 5 & 6 & 5 & 6 & 8 & & 0.545 & 0.545 & 0.341 & 0.513 & 0.383 & 0.374 & 0.404 & 0.467 & 0.224 & 0.141 & 0.201 \\
\hline 6 & 6 & 7 & 8 & 9 & 6 & & 0.545 & 0.545 & 0.732 & 0.460 & 0.674 & 0.606 & 0.584 & 0.449 & 0.282 & 0.464 \\
\hline 7 & 8 & 8 & 11 & 8 & 6 & 6 & & 0.545 & 0.659 & 0.767 & 0.674 & 0.606 & 0.584 & 0.599 & 0.423 & 0.530 \\
\hline 8 & 10 & 18 & 15 & 11 & 5 & 8 & 8 & & 0.555 & 0.756 & 0.678 & 0.548 & 0.659 & 0.730 & 0.668 & 0.741 \\
\hline 9 & 10 & 13 & 15 & 15 & 7 & 10 & 9 & 11 & & 0.590 & 0.629 & 0.667 & 0.595 & 0.572 & 0.369 & 0.583 \\
\hline 10 & 9 & 11 & 15 & 10 & 5 & 6 & 10 & 14 & 10 & & 0.789 & 0.608 & 0.719 & 0.728 & 0.562 & 0.625 \\
\hline 11 & 7 & 12 & 13 & 9 & 5 & 9 & 9 & 13 & 11 & 13 & & 0.595 & 0.706 & 0.706 & 0.598 & 0.653 \\
\hline 12 & 5 & 6 & 8 & 8 & 4 & 6 & 6 & 7 & 8 & 8 & 7 & & 0.635 & 0.510 & 0.322 & 0.535 \\
\hline 13 & 4 & 3 & 6 & 6 & 4 & 5 & 5 & 7 & 6 & 7 & 7 & 5 & & 0.605 & 0.289 & 0.461 \\
\hline 14 & 9 & 15 & 15 & 9 & 3 & 6 & 8 & 14 & 10 & 12 & 12 & 6 & 6 & & 0.762 & 0.804 \\
\hline 15 & 7 & 17 & 14 & 6 & 2 & 4 & 6 & 14 & 7 & 10 & 11 & 4 & 3 & 14 & & 0.871 \\
\hline 16 & 10 & 22 & 19 & 11 & 3 & 7 & 8 & 17 & 12 & 12 & 13 & 7 & 5 & 16 & 19 & \\
\hline
\end{tabular}




\section{Ecological Analysis of the Thanatocoenoses}

The species composition of bivalve molluscs and the taphonomic conditions of the formation of thanatocoenoses in the open and semi-closed regions appear to be quite different. Table 2 shows the similarity indices of species composition among the areas within the open and semiclosed regions. The percentage of species in common for both types of regions is $35 \%$ to $60 \%$ of the total number of species. In order to determine the origin of these differences, we have undertaken an ecological analysis of the thanatocoenoses based on the list of species.

The composition and distribution of upper subtidal molluscs in Possjet Bay is mainly controlled by two factors, temperature and salinity (Golikov \& Scarlato, 1967a,b). Molluscan temperature telerance is closely correlated with their biogeographical distribution; therefore, biogeographical composition of a molluscan fauna can be good evidence for detecting differences in temperature regimes in different regions. In our case, the biogeographical categories of the taxa, taken from Scarlato (1981), may be used also as ecological ones. In doing so we use the zonal geographical terminology accepted in Russian biogeographical literature (see review: KuSSAKIN, 1990). A full explanation of the biogeographical characteristics of the species is given by Lutaenko (1993). Twenty-six species, which comprise $46 \%$ of the total number discovered in the beach zone of Possjet Bay are subtropical and subtropical-subboreal, while the others are widely distributed boreal and amphiboreal, tropical-subtropical and arcticboreal species (Fig. 2). Such a proportion reflects the well known law that warm-water taxa are concentrated in shallow waters in the middle latitudes, although the bathymetric ranges of the same species in tropical latitudes are much broader. Golikov \& Scarlato (1967b) showed that the warm-water subtropical and subtropical-subboreal molluscs, live mainly in depths down to 10 metres in Possjet Bay, 76\% of them
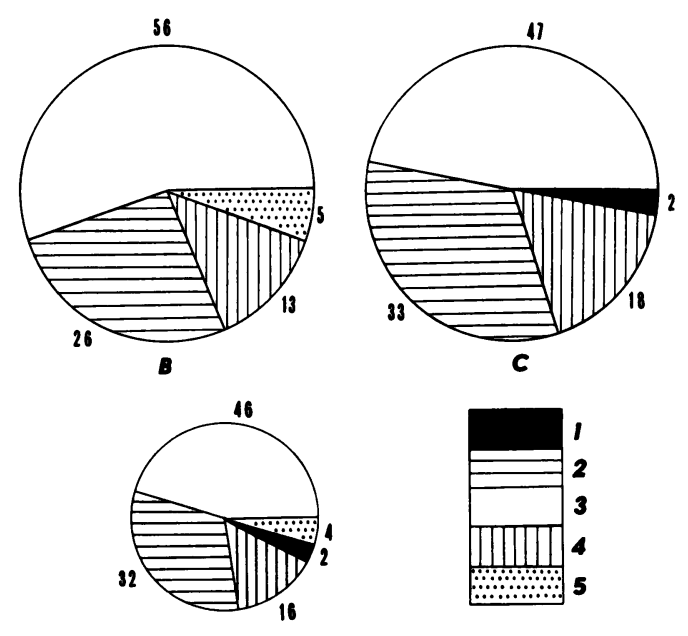

A

Fig. 2 Biogeographical composition of bivalve molluscs from the beaches of Possjet Bay: A - in total, B - in semi-closed regions, $\mathrm{C}$ - in open regions.

1 - boreal-arctic species

2 - subboreal species

3 - subtropical + subtropical-subboreal + subtropical-boreal species

4 - widely distributed boreal + amphiboreal (circum-boreal) species

5 - tropical-subtropical species

inhabiting depths no deeper than 5 metres. In deeper waters, the number of subtropical and subtropical-subboreal species decreases and they disappear below 25 metres. Bottoms deeper than that are inhabited mainly by cold-water, arctic-boreal molluscs, which begin to occur sparsely from 25-30 metres, although most of them are known from waters deeper than 60 metres. Observations in different parts of the Barents Sea and the Sea of Japan (MAximova, 1974; EvseEv, 1981) have shown that mollusc shells and other benthic remains are brought to the beach from a relatively narrow zone restricted to the upper $15-20$ metres, rarely to 30 
metres. The proportion of biogeographical groups of molluscs in the beach thanatocoenoses of Possjet Bay suggests that the shell materials come from shallow waters. Observations on the biogeographical groups on the open and semi-closed coasts, respectively (Fig. 2), suggest that warm-water taxa (56\%) predominate in the semi-closed bights. The proportion of subtropical and subtropical-subboreal molluscs strongly decreased in the open areas, where tropical-subtropical species were totally lacking. The arctic-boreal species appear on the open coasts instead of these warmwater elements. The same differences in distribution of warm-, temperate- and cold-water living animals were revealed during investigations of the bottom communities of Possjet Bay (Golikov \& Scarlato, 1967a). This is connected with the heterogeneity of summer temperatures in the Bay, which allows the warm-water taxa to concentrate in the semi-closed bights under good conditions for summer spawning. Thus, the "biogeographical structure" of the beach thanatocoenoses reflects the real differentiation of the biogeographical composition of the upper subtidal molluscs quite well.

The degree of fresh-water dilution can be estimated by comparing the relative abundance of euryhaline and brackish-water molluses to stenohaline molluscs. The stenohaline species inhabit mainly waters from 28 to $33-34 \%$ (SCARlato, 1981). The percent of stenochaline species tends to decrease, whereas the percentage of euryhaline species increases simultaneously with the appearance of brackish-water molluses in regions subject to fresh-water dilution. The stenohaline species comprise $27-82 \%$ of the total number of species in different areas of Possjet Bay's beaches (Fig. 3). They tend to be most dominant along the open parts of the coast, comprising $77-82 \%$ of the species ( $79 \%$ on average), and also at the mouths of the semiclosed bights, comprising 77 and $76 \%$, respectively, in areas 8 and 14. The brackish-water and euryhaline species increased in the semi-

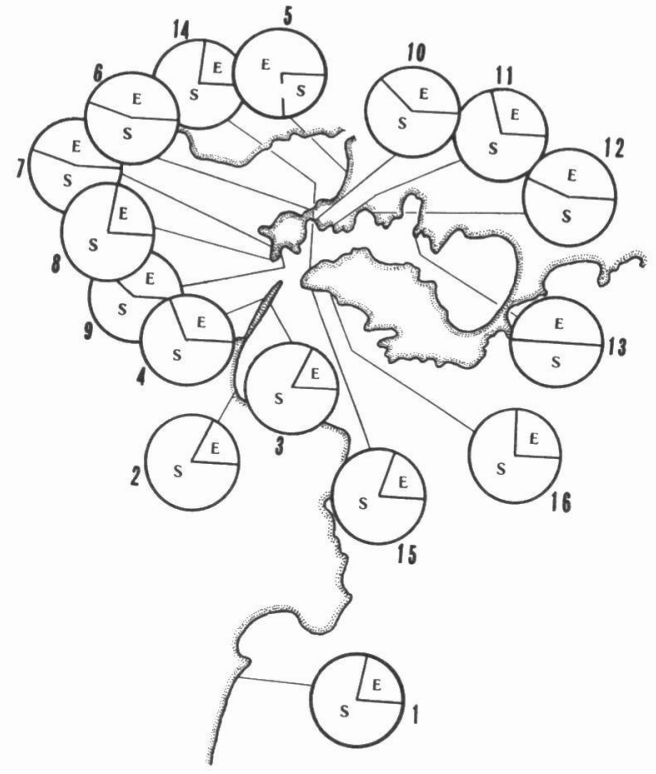

Fig. 3 The relation between stenohaline (S) and euryhaline + brackish-water (E) species of bivalve molluscs along the coast of Possjet Bay.

closed bights, whereas the stenohaline species comprise from $27 \%$ (near the mouth of the Gladkaya River-area 5) to $71 \%$ (area 10) (56\% on average).

The distribution of bivalve molluscs in the upper subtidal zone is strongly controlled by the type of bottom sediments. Great numbers of bivalves show a good fidelity to a particular type of substrate. The typical associations existing under strong sediment control can be, therefore, found in the subtidal zone. Their distribution in the beach zone, however, is not always clearly traced because of the wide variety of substrates within a single small region and their sporadic or "belt-like" distribution. 


\section{Conclusions}

Our data suggest that environmental mixing of shells in Possjet Bay does not play a significant role in the formation of thanatocoenoses. The taxonomic composition of the thanatocoenoses on the beaches of most areas is not ecologically incompatible with that of the living communities in the nearshore zone of the same areas and reflects well the molluscan natural habitats. The differences between the thanatocoenoses of open and semi-closed regions show a good correspondence with hydrobiological data for these regions (Golikov \& SCARlato, 1965, 1967a,b, 1968; SCARlato et al., 1967). This suggests the absence of significant shell migration along the shore in Possjet Bay. Molluscan shells are probably not transported at all between the open and semi-closed coasts. It is well known that transportation plays a significant part in causing losses and disturbances during the formation of molluscan postmortem assemblages (see review: Kidwell \& BosenCE, 1991). The geomorphology of Possjet Bay is not favourable for the formation of long nearshore currents (KoRotKy \& KHUdyaKov, 1990), which promote transportation along the shore. Thus, on the basis of this study, it can be concluded that the beach molluscan thanatocoenoses in Possjet Bay are essentially sub-autochtonous assemblages. This conclusion substantiates the view that sub-autochthonous thanatocoenoses are undely distnbited, regular features of marine actuopaleontology and taphonomy in the recent coastal zone and that allochthonous ones ave rare (LUTAENKo \& OLEYNIK, 1992). An analysis of extensive literature shows that out-ofhabitat transport of shells is rare in levelbottom, sublittoral environments (KIDWELL \& BOSENCE, 1991).

\section{Acknowledgments}

I wish to intend my thanks to D.I. VySHKVARTZEV and E.B. LEBEDEV (Institute of
Marine Biology, Far East Branch of the Russian Academy of Sciences) for help in field collecting. I am also indebted to A.E. OleyniK (Purdue University, Indiana) and T. Koznova (Institute of Marine Biology, FEB RAS) for translating the Russian manuscript of this paper.

\section{References}

Ansell, A.D., L. Robb and H.T. Powell, 1988. Algal-induced dislodgement as a cause of bivalve mortality on some Scottish beaches. J. Mar. Biol. Assoc. U.K., 68: 219-233.

DAvis, R.A., 1985. Beach and nearshore zone. In, Coastal sedimentary environments, ed. by R.A. Davis, Springer, Berlin, pp. 379-444.

Evseev, G.A., 1981. Communities of bivalve molluscs in post-glacial deposits on the shelf of the Sea of Japan. Nauka, Moscow, $160 \mathrm{pp}$. (in Russian, title translated)

Golikov, A.N. and O.A. Scarlato, 1965. Hydrobiological explorations in the Possjet Bay with diving equipment. Issled. Fauny Morei (Explor. Fauna Seas), 3 (11): 5-21. (in Russian)

Golikov, A.N. and O.A. Scarlato, 1967a. Ecology of bottom biocoenoses in the Possjet Bay (the Sea of Japan) and the peculiarities of their distribution in connection with physical and chemical conditions of the habitat. Helgoländer wiss. Meeresunters., 15: 193-201.

Golikov, A.N. and O.A. Scarlato, 1967b. Molluscs of the Possjet Bay (the Sea of Japan) and their ecology. Trudy Zool. Inst. Akad. Nauk SSSR (Trans. Zool. Inst. Acad. Sci. USSR), 42: 5-154. (in Russian)

Golikov, A.N. and O.A. Scarlato, 1968. Vertical and horizontal distribution of biocoenoses in the upper zones of the Japan and Okhotsk Seas and their dependence on the hydrological system. Sarsia, 34: 109-116.

Golikov, A.N. and O.A. Scarlato, 1971. On the fauna of molluscs from the Possjet Bay of the Sea of Japan. Issled. Fauny Morei 
(Explor. Fauna Seas), 8 (16): 188-205. (in Russian)

Kafanov, A.I., 1991. Shelf and continental slope bivalve molluscs of the Northern Pacific Ocean: A check-list. Far East Br. Acacl. Sci. USSR, Vladivostok, 200 pp. (in Russian)

KaLAShnikov, V.Z., 1984. The impact of surf waves induced by "Alis" typhoon on the population of the clam Patinopecten yessoensis in the Possiet (Possjet) Bay of the Sea of Japan. Biol. Mor. (Mar. Biol., Vladivostok), 1: 55-59. (in Russian)

Kidwell, S.M. and D.W.J Bosence, 1991. Taphonomy and time-averaging of marine shelly faunas. In, Taphonomy. Releasing the data locked in the fossil record, ed. by P.A. Allison and D.E.G. Briggs, Plenum Press, N.Y. and London, pp. 116-209.

Korotky, A.M. and G.I. KhUdyakov, 1990. Exogenic geomorphological systems of the sea coasts. Nauka, Moscow, $216 \mathrm{pp}$. (in Russian, title translated)

Kussakin, O.G., 1990. Biogeography of isopod crustaceans in the Boreal Pacific. Bull. Mar. Sci., 46: 620-639.

LutAenko, K.A., 1990. Bivalve molluscs in the beach zone of Peter the Great Bay (sea of Japan). Inst. Mar. Biol., Far East Branch, USSR Acad. Sci. Preprint 28: 1-51. (in Russian, title translated)

Lutaenko, K.A., 1993. Climatic optimum during the Holocene and the distribution of warmwater molluscs in the Sea of Japan. Palaeogeogr., Palaeoclimatol., Palaeoecol., 102: 273-281.

Lutaenko, K.A. and A.E. Oleynik, 1992. Actuopaleontology and formation of fossil record incompleteness. Izv. Akad. Nauk, ser. biol. (Proc. Acad. Sci., ser. biol.), 4: 582-589. (in Russian)

Maximova, S.V., 1974. Comparative characteristics of some biotopes of nowaday and fossil seas. Trudy Inst. Geol. i Geofiz. Sibir. Otd. Akad. Nauk SSSR (Trans. Inst. Geol. Geophys. Siber. Branch Acad. Sci. USSR),
84: 62-72. (in Russian)

Pesenko, Yu.A., 1982. Principles and methods of quantitative anaslysis in faunistic investigations. Nauka, Moscow, 287 pp. (in Russian, title translated)

Rakov, V.A. and A.V. Kucheryavenko, 1977. The influence of typhoon "Vera" on the bottom fauna of the Possjet Bay (the Sea of Japan). Issled. Biol. Ryb $i$ Promysl. Okeanogr. (Investig, Fish Biol. Fish. Oceanogr., Vladivostok), 8: 26-34. (in Russian)

Scarlato, O.A., A.N. Golikov, S.V. Vasilenko, N.L. Tzvetkova, E.N. Grusov and K.N. NeSIS, 1967. Composition, structure and distribution of bottom biocoenoses in the coastal waters of the Possjet Bay (the Sea of Japan). Issled. Fauny Morei (Explor. Fauna Seas), 5(13): 5-61. (in Russian)

SCARlato, O.A., 1981. Bivalve molluscs of temperate latitudes of the western portion of the Pacific Ocean. Opred. Faune SSSR (Guide-books Fauna USSR), 126: 1-479. (in Russian, title translated)

Scarlato, O.A. and A.I. Kafanov, 1988. Contribution to the fauna of bivalve molluscs in the USSR Far East seas. Zool. Zh. (Zool. J.), 67:937-942. (in Russian)

Vyshkvartzev, D.I., 1984. Physical-geo graphical and hydrochemical characteristics of the shallow bights of Possjet Bay. In, Hydrobiological investigations of bays and gulfs of primoriye, ed. by A.I. KAFANOV, Vladivostok, Far East Sci. Centr. USSR Acad. Sci. pp. 4-11. (in Russian, title translated)

Vyshingartzev, D.I., E.B. Levedev and V.Z. Kalashnikov, 1990. Consequences of the typhoon "Vera" : casting of invertebrates on a sandy spit in Possjet Bay of the Sea of Japan. Biol. Mor. (Mar. Biol., Vladivostok), 5: 78-80. (in Russian) 


\section{和文要旨}

コンスタンチン・ルタエンコ 日本海, ポシェッ 卜湾における貝類遣骸群集一特に波浪の強い海岸と弱 い海岸における比較

日本海西北部のポシェット湾（ピョートル大帝湾 の南西部）16地点の海岸の貝類㟟骸群集について調べ， 23 科, 42 属, 58 種の二枚貝同定した。これは，この湾 と周辺地域に生息する貝類の約 $60 \%$ にあたる. その種 構成の特徽と遺骸群集の化石化過程について記述した。 海岸性の貝類遗骸群集の種構成は，その湾の海域の環
境に影笠されていた．ポシェット湾における死後運搬 作用は僅かであることが示唆された。

Konstantin A. Lutaenko

Laboratory of Benthos Ecology, Institute of Marine Biology, Far East Branch of Russian Academy of Sciences, Vladivostok 690041 and Zoological Museum, Far East State University, Vladivostok 690000 , Russia. 